\title{
Reframing water-related ecosystem services flows
}

Jingyu Lin ${ }^{1,2}$, Jinliang Huang ${ }^{1 *}$, Michalis Hadjikakou ${ }^{2}$, Yaling Huang ${ }^{3}$, $\mathrm{Kun}^{4}{ }^{4}$, Brett A. Bryan $^{2}$

${ }^{1}$ Coastal and Ocean Management Institute, College of the Environment and Ecology, Xiamen University, 361102 Xiamen, China

${ }^{2}$ Centre for Integrative Ecology, Deakin University, Burwood, Vic 3125, Australia

${ }^{3}$ Institute of Oceanography, Minjiang University, 350100 Fuzhou, China

${ }^{4}$ Faculty of Resources and Environmental Science, Hubei University, 430062 Wuhan, China

Corresponding author: Jinliang Huang (jlhuang@,xmu.edu.cn), ORCID: https://orcid.org/0000-0002-0895-3418 


\begin{abstract}
To sustain water-dependent economic and socio-ecological systems, natural capital and its interactions with other capitals is gaining attention, but a clear understanding of how to manage natural capital sustainably and how to make decisions relevant to waterrelated ecosystem services is yet to be achieved. In this study, we extended the framing of water-related ecosystem service flows as a cycle, integrating water quantity and quality and capturing the flows of ecosystem services (i.e., green phase) and ecosystem disservices (i.e., red phase), and connecting natural capital, built capital, and beneficiaries. We applied this framework to the Jiulong River watershed in China, using hydrological models to model water quantity and quality based on historical observations and experimental data. Our results showed that, during the green phase, the interactions of natural capital and built capital significantly improved water quality in downstream areas with higher flows. During the red phase, built capital reduced ecosystem disservices by $\sim 10 \%$ while natural capital further reduced it by over one half. Our framework can provide information for natural capital management, ecocompensation, and pollutant management relevant to water-related ecosystem services.
\end{abstract}




\section{Graphic for TOC/Abstract Art:}

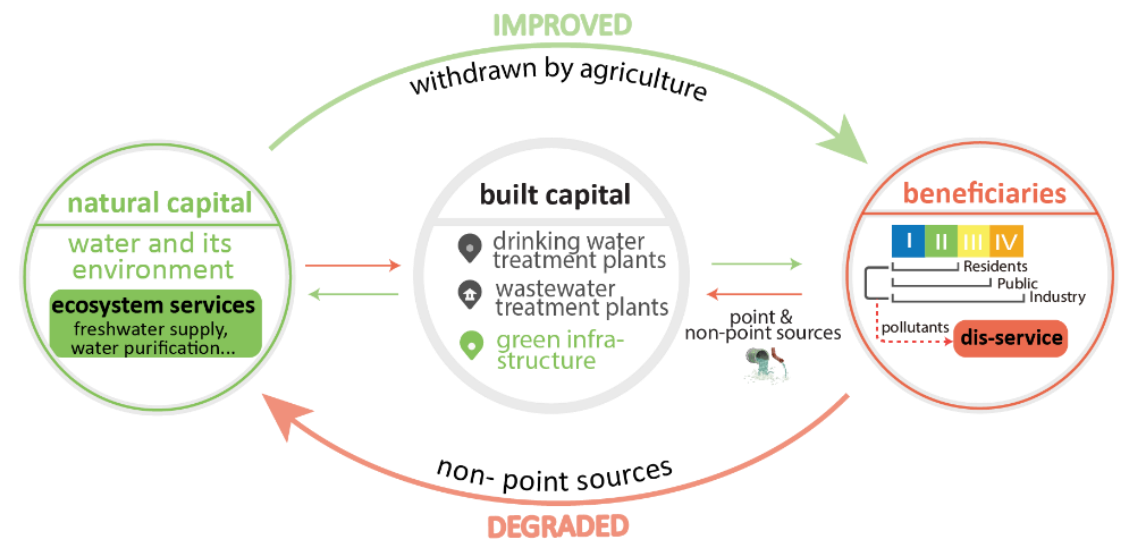

\section{Synopsis:}

We extended the framing of ecosystem service flows as a cycle to inform the management of water-related ecosystem services.

Keywords: ecosystem disservice, ecosystem service cycle, natural capital, built capital, beneficiaries, interactions, ecosystem service flow. 


\section{Introduction}

The concept of natural capital is gaining worldwide attention for its ability to inform sustainable management of social-ecological systems. Natural capital refers to the living and non-living components of ecosystems that directly or indirectly provide services for human beings (Guerry et al., 2015). Yet, natural capital cannot provide services to beneficiaries without the presence of people (i.e., human capital), communities (i.e., social capital), and the built environment (i.e., built capital; Costanza et al., 2014). Natural capital must therefore interact with other forms of capital to realize its benefits (Costanza et al., 2017).

Recent studies have measured the provision of ecosystem services (ES) by accounting for not only stocks of natural capital but also other forms of capital. For example, the effects of human-derived products, technology, and infrastructure (i.e., built or manufactured capital) as well as trust, community involvement, and social cohesion (i.e., social capital) are increasingly being considered in combination with natural capital (Bateman and Mace, 2020; Barnes-Mauthe et al., 2015; Chen and Graedel, 2015; Jone et al., 2016).

A broader consideration of the influence of multiple types of capital is essential to meeting the challenge of sustainability of natural capital and ES (Schröter et al., 2017). Despite much progress in recent decades, a clear understanding of how natural capital interacts with other capitals to produce ES flows to beneficiaries remains elusive (Jones et al., 2016). Several elements have been proposed to improve this understanding, including measuring ES supply, demand, and beneficiaries (Lin et al., 2020); characterizing the whole ES chain (Mandle et al., 2020); and identifying mediating factors in ES delivery (Mandle et al., 2020).

However, ES flow was initially defined as a single flow from suppliers to beneficiaries (Bagstad et al., 2014), and current thinking has not expanded on the ES chain from this one-way flow (Jone et al., 2016; Koellner et al., 2018; Palmer and Rubi, 2019), leading to only a partial understanding of ES dynamics. For some ESs, conceptualizing ES flows as a cycle that is affected by different types of capital, instead 
of a one-way flow from suppliers to beneficiaries, can enable a more comprehensive and sophisticated understanding of ES dynamics. In addition, few studies have considered what becomes of ESs once they have been used by beneficiaries. For at least some ecosystem goods and provisioning services, such as freshwater and food, byproducts are generated following use (Martin-Ortega et al., 2015). This often takes the form of degradation of the resource or stock in terms of quality or quantity (Maseyk et al., 2017).

Water is one component of natural capital and water-related ESs such as freshwater supply (i.e., water quantity) and water purification (i.e., water quality) show complex cyclical dynamics (Keeler et al., 2012). Hydrological processes determine ecohydrological functions through impacts on water quantity, quality, location, and timing and their effects on water availability to beneficiaries (Brauman, 2015). This waterrelated ES is provided to different beneficiaries such as industry, agriculture, and human drinking, generating water-related ES flows (Bagstad et al., 2014). ES flows interact with different forms of capital, where, for example, industry and domestic sectors obtain water from treatment plants and pipes (i.e., built capital) (Meehan et al., 2020). This built capital thus provides and mediates essential services for human well-being (Weisz et al., 2015).

To illustrate and analyze the complex interactions between capital types in waterrelated ES flows, here, we focus on nitrogen, an essential nutrient required for the maintenance of Earth's biological systems (Palmer et al., 2017). Substantial amounts of nitrogen are released into ecosystems via run-off, leading to increases in riverine nitrogen concentrations and eutrophication (Clark et al., 2017; Guo et al., 2020; Motallebi et al., 2018). This phenomenon degrades the eco-hydrological function of aquatic ecosystems, thereby converting water-related ESs into an ecosystem disservice (ED; Krkoška et al., 2016). EDs are negative environmental effects resulting from anthropogenic impacts, including the release of substances or side effects of the deliberate manipulation of ecosystems (Lyytimäki et al., 2009). EDs interact with ESs (von Döhren and Haase, 2015) where, for example, applying more nitrogen enhances vegetation growth and water interception by plants, thereby affecting water availability 
for people (Jones et al., 2014).

Biophysical models provide a useful framework to capture interactions between different forms of capital and ES flows (Kim et al., 2017). Water-quality models can estimate how changing capital and ES management affect nitrogen loading to downstream endpoints of a watershed (Keeler et al., 2012). They can also be used to identify nitrogen sources and retention processes in terrestrial and aquatic ecosystems by accounting for nitrogen discharge originating from effluents (e.g., drained from built capital) or agricultural activities (i.e., beneficiaries; Alexander and Gorman Sanisaca, 2019; Zhou et al., 2018). Basin-scale runoff models could be applied to simulate water quantity from various land uses by computing hydrological cycle components such as evapotranspiration, infiltration, interflow, and base flow (Lin et al., 2020). As water quality is sensitive to changes in water quantity, it is important to integrate these two aspects when quantifying interactions between different forms of capital and waterrelated ESs (Murphy and Sprague, 2019).

Here, we propose a new framework to account for the complex interactions among natural capital, built capital, beneficiaries, and the site-specific flows of waterrelated ESs. To evaluate and demonstrate its effectiveness, we apply the framework in the Jiulong River watershed in China. The study area supports extensive crop and livestock production, has experienced rapid urbanization, and provides drinking water to over 12 million people. We first assessed water quantity using the Hydrological Simulation Program FORTRAN (HSPF) model to estimate streamflow. We modeled water quality using the SPAtially Referenced Regression On Watershed attributes (SPARROW) model. We used information on water-related ES supply and ES beneficiaries (i.e., the agricultural, domestic, public, and industrial sectors) to calculate water-related ES flows and identify the green and red phases of the ES cycle. The framework and its application provide a novel and more comprehensive understanding of the water-related ES cycle to inform specific decision-making contexts to achieve sustainable management of natural capital for different areas. 


\section{Methods}

\subsection{Study framework}

We reframed the conceptualization of water-related ES flows as a cycle comprising a green phase and a red phase with three components: natural capital, built capital, and beneficiaries (Figure 1). Of these components, built capital works as a mediating factor. Natural capital serves as a sending system while beneficiaries act as a receiving system. We considered water and its environment as natural capital following the framework of the System of Environmental-Economic Accounting for Water (UNSD, 2012). Landscapes and ecosystems generate multiple water-related ES, including freshwater provisioning (i.e., water quantity) and water purification (i.e., water quality) as defined in the Common International Classification of Ecosystem Services (Haines-Young and Potschin, 2012). Water quantity and water quality in a water body were considered final ESs following Haines-Young and Potschin (2010).

Via a range of eco-hydrological processes, natural capital can improve water quality by reducing turbidity, removing contamination by heavy metals, and reducing concentrations of pollutants such as nitrogen. As mediated through built and human capital, people derive many benefits from water-related ESs. Agriculture typically obtains water directly from rivers and water bodies for irrigating crops and pastures, which can tolerate water of variable quality. Water for domestic and industrial consumption is often subject to treatment via built capital to improve quality to drinking standards. This process is thus characterized as a green phase.

Conversely, EDs flow from beneficiaries to nature, generating negative impacts on ecosystems in the red phase. Water-related ESs are consumed by different beneficiaries such as the agricultural, domestic, public, and industrial sectors. During this process, some water resources are no longer available to the ecosystem (e.g., electricity production involves large-scale evaporation), while some are contaminated via point sources (e.g., sewage and industrial outflows) and non-point sources (e.g., agricultural run-off) and polluted by chemical substances such as nitrogen, which transforms ESs into EDs. EDs (i.e., effluents) return to the ecosystem directly or 
indirectly with an accompanying pollutant load. EDs can erode biodiversity and ecological processes when entering waterways via non-point source pollution. Alternatively, EDs may be delivered via wastewater treatment plants, which partly limit pollutant loads and ecological impacts. Additionally, ecological restoration and rehabilitation programs promote green infrastructure to reduce EDs from wastewater treatment plants. The effluent discharged from built capital is then purified by natural capital and stored as natural capital assets.

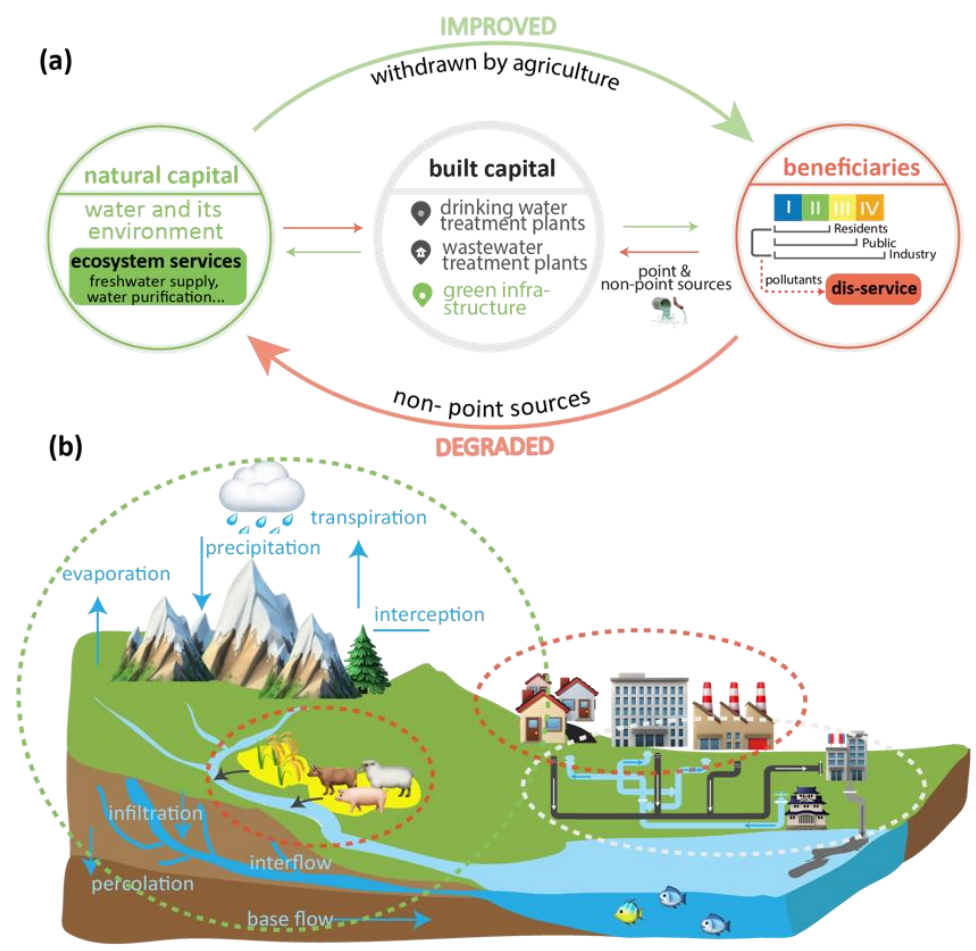

Figure 1. Water-related ecosystem services cycle to assess ecosystem services flow via the integration of natural capital, built capital, and beneficiaries. Panel (a) shows the water-related ecosystem services cycle, while the bottom panel (b) shows real-world interactions (refers to A-Level Geography (2018)). The green arrow indicates improvements in water quality, while the red arrow indicates decreases in water quality.

\subsection{Study area}

The Jiulong River watershed is located in the southeastern area of Fujian Province, China. The Jiulong River includes two major tributaries, the North River and West River, with a drainage area of $\sim 1.4$ million ha converging in Zhangzhou and Longyan Cities 
(Figure 2). The watershed has an annual discharge flow of $\sim 1.2 \times 10^{6} \mathrm{GL}$ drained into estuarine and coastal waters. As an essential water source for Longyan, Zhangzhou, and Xiamen Cities, the Jiulong River supports over 12 million people as of 2019 according to the Statistics Yearbook in Longyan (2020), Zhangzhou (2020), and Xiamen (2020). Agriculture has intensified in the Zhangzhou plain since the 1990s with orchards of bananas, longans, red grapefruits, and lychees as well as livestock breeding, leading to the eutrophication of water bodies (Zhou et al., 2018). Significant amounts of effluent and manure from piggeries have been discharged into the North River, leading to a large dinoflagellate bloom in the watershed in January 2009 (Du et al., 2013). Pollutant management, particularly nitrogen, is therefore critical to water resources and sustainability in the study area.

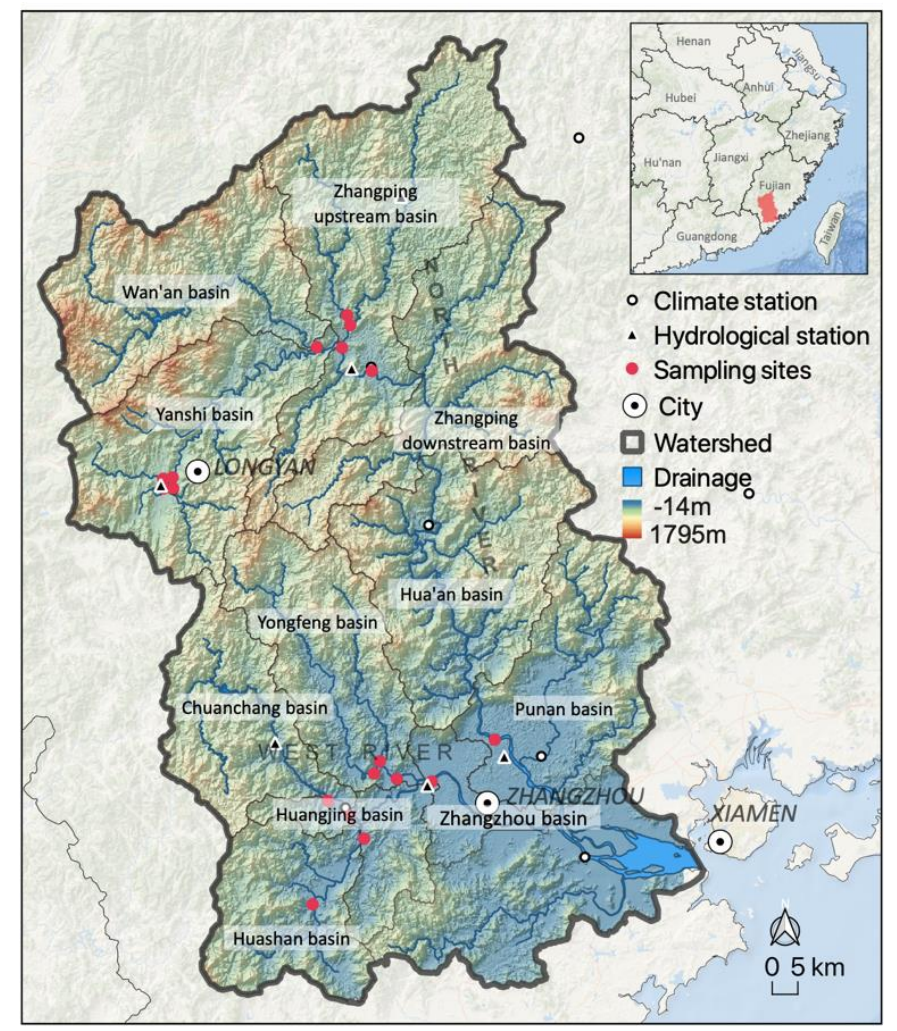

Figure 2. The Jiulong River watershed in Fujian Province, China.

\subsection{Ecosystem services cycle}

\subsubsection{Natural capital}

To characterize the ecosystem services cycle, we first quantified natural capital in the 
study area. We derived a watershed drainage division vector dataset with the Arc-Hydro add-in in ArcGIS 10.7 based on a Digital Elevation Model acquired from the Spatial Information Research Centre of Fujian. We established the watershed boundary and study area; 95 sub-catchments were identified based on drainage areas and topography. Sub-catchments were merged into 11 basins as indicated in Figure 2. Land-use maps at 30-m resolution for 2017 were obtained from Gong et al. (2019).

Water quantity was assessed using the HSPF model. Daily meteorological data (i.e., precipitation, maximum and minimum temperatures, average wind speed, average cloud cover, and average dew point) for 10 weather stations from 2011 to 2017 were acquired from the China Meteorological Data Service Center and used to create meteorological files for the HSPF model. Historical daily streamflow data at the outlets of the Punan and Zhengdian hydrological stations from 2011 to 2017 were collected from the Hydrological Bureau of Fujian Province. Flow routing was identified as the direction of water flow via the HSPF model based on a tanks-in-series model. The accuracy of the HSPF model was assessed using $\mathrm{R}^{2}$ and Nash-Sutcliffe efficiency ( $\mathrm{E}_{\mathrm{NS}}$ ).

We assessed water quality based on total nitrogen $(\mathrm{TN})$ concentration using the RSPARROW model. Three types of variables are necessary to model water quality in RSPARROW: pollutant sources, land-water delivery factors, and other fixed variables. All data sources are detailed in Table S1. Monthly surface water samples were collected from 2015 to 2018 at 18 sites located at the outlets of select sub-catchments in the Jiulong River watershed, with 10 sites located in the North River and 8 sites located in the West River (Figure 2). Detailed information on water samples is provided in the Supplementary Information. Uncertainty (i.e., 95\% confidence intervals) in the TN model for each sub-catchment was calculated with 200 iterations of Monte Carlo sampling. A sample of 200 is typically sufficient to obtain robust estimates of prediction uncertainties (Alexander and Gorman Sanisaca, 2019).

As it is difficult to separate nitrogen sources into different species, such as sources of ammonia nitrogen $\left(\mathrm{NH}_{4}^{+}\right)$and nitrate $\left(\mathrm{NO}_{3}{ }^{-}\right)$from fertilizers, we modeled RSPARROW-TN as a proxy for water quality. However, according to the environmental quality standards for surface water in China (GB3838-2002), there is no 
benchmark for riverine water quality regarding TN. Therefore, the concentration of TN was converted to $\mathrm{NH}_{4}{ }^{+}$by multiplying $\mathrm{TN}$ by 0.3 following the analysis of historical monitoring data (2015-2018; Figure S4).

\subsubsection{Beneficiaries}

Following Lin et al. (2020), we identified water-related ES beneficiaries as the actual anthropogenic use (i.e., consumption) of water-related ES, including by agricultural, domestic, public, and industrial sectors. Annual water demand in each grid cell was calculated as:

$$
\begin{aligned}
& W_{t o t}=W_{d o m}+W_{p u b}+W_{i n d}+W_{a g r} \\
& W_{d o m}=I_{d o m} \times P \times 365 / 1,000 \\
& W_{p u b}=I_{p u b} \times P \times 365 / 1,000 \\
& W_{i n d}=I_{\text {ind }} \times L_{i n d} \times V \times E \\
& W_{a g r}=I_{\text {agr }} \times L_{\text {agr }}
\end{aligned}
$$

Where $W_{\text {pub }}, W_{\text {dom }}, W_{\text {ind }}$, and $W_{\text {agr }}$ represent public, domestic, industrial, and agricultural demand for water, respectively. $I_{d o m}$ indicates the average daily residential water use per capita in each city $\left(\mathrm{L}_{\text {person }}{ }^{-1}\right.$ day $\left.^{-1}\right)$, while $I_{p u b}$ indicates the average daily public water use (e.g., by government) per capita in each city $\left(\mathrm{L} \mathrm{person}^{-1}\right.$ day $\left.^{-1}\right)$. Factors 365 and 1,000 are used to convert domestic water demand from $\mathrm{L}_{\text {person }}{ }^{-1}$ day $^{-}$ ${ }^{1}$ to $\mathrm{m}^{3}$ person $^{-1}$ year $^{-1}$. I ind represents the average annual industrial water use for each RMB 10,000 ( 1,422 USD) of industrial value added (i.e., $\mathrm{m}^{3}$ per RMB 10,000 industrial value added). $V$ is the industrial value added per hectare (RMB 10,000 ha ${ }^{-1}$ ). $I_{a g r}$ represents the average annual water use for irrigation per hectare $\left(\mathrm{m}^{3} \mathrm{ha}^{-1}\right)$. We assumed that agriculture always received water nearest to its location with no effect of water quality. $L_{\text {ind }}$ indicates built-up land area (ha) while $L_{\text {agr }}$ indicates agricultural land area (ha). $P$ stands for the population in each grid cell, collected from the Institute of Geographic Sciences and Natural Resources Research, Chinese Academy of Sciences. These four indices $\left(W_{p u b}, W_{d o m}, W_{\text {ind }}\right.$, and $\left.W_{a g r}\right)$ are spatial layers at a 
resolution of $30-\mathrm{m}$ grid cells. $E$ is the proportion of industrial land in built-up areas with $E \approx 0.3$ in the Jiulong River watershed. All socio-economic data sources are provided in the Supplementary Information.

\subsubsection{Built capital}

Drinking water treatment plants and wastewater treatment plans were included as built capital. Information on drinking water treatment plants was obtained from the Fujian Provincial Department of Environment Protection (2020). Information on wastewater treatment plans was collected from the Ministry of Ecology and Environment of the People's Republic of China (MEE, 2020).

\subsubsection{Water-related ecosystem services cycle}

The assessment of the ES cycle included ES flow and ED. For ES flow, differences between the 30-m resolution spatial layers of water-related ES supply and beneficiaries were calculated. We summed up the differences in each basin as water surplus. When ES flow satisfied the demand of a local area, the remaining water flowed from basin to basin, accumulating from upstream to downstream following the hydrography of the basin.

EDs equaled the total amount of nitrogen load drained from beneficiaries, such as sewage from domestic use, industry, deposition from precipitation, and agriculture to the environment. There are three phases of nitrogen loads: 1) loads generated by beneficiaries, 2) loads discharged after removal from built capital, and 3) riverine nitrogen loads. Nitrogen loads generated from sewage discharge of domestic use were computed based on the population in each county multiplied by the sewage production coefficient derived from The Second China Pollution Census (SCIES, 2019). The production coefficient was replaced with the effluent coefficient to calculate nitrogen loads discharged from domestic use. Nitrogen loads and effluent from sewage discharge from industry were collected from the Statistical Yearbook (2018). Nitrogen loads generated from livestock manure were calculated by multiplying the abundance of 
different livestock types and the livestock production coefficient reported in The First China Pollution Census (SCIES, 2008). The production coefficient was replaced with the effluent coefficient to compute nitrogen loads discharged from livestock. Detailed information on production coefficients and effluent coefficients can be found in Table S4. Fertilizer application data were derived from the Statistical Yearbook (2018) in Longyan, Zhangzhou, Quanzhou, and Xiamen Cities. All Statistical Yearbook data were derived from the China Statistical Yearbooks. Riverine nitrogen loads for different sources were modeled using the RSPARROW model. We used the zonal statistics tool in ArcGIS to calculate EDs for each basin.

\section{Results}

\subsection{Natural capital}

During calibration, the HSPF model predicted water quantity with a monthly ENS $_{\mathrm{N}}$ 0.79 and $\mathrm{R}^{2}$ of 0.80 (Figure $\mathrm{S} 1$ ). During validation, we computed an $\mathrm{E}_{\mathrm{NS}}$ of 0.65 and $\mathrm{R}^{2}$ of 0.61 in the North River. For the West River, monthly $E_{N S}$ was 0.65 and $R^{2}$ was 0.78 during calibration, while monthly $\mathrm{E}_{\mathrm{NS}}$ was 0.65 and $\mathrm{R}^{2}$ was 0.66 during validation. Those indicators indicated good model performance. A scatterplot of observed versus predicted water quality (i.e., nitrogen load) is shown in Figure S2. Model fit was generally unbiased with efficient performance in the study area (Figure S2). A closer look at the overall statistical fit of the RSPARROW model indicated that model skill was strong for predicted load $\left(\mathrm{RMSE}=0.39-0.40, \mathrm{R}^{2}=0.93, \mathrm{R}^{2}\right.$ Yield $=0.92$; Table S2). Sub-catchments with small areas had higher uncertainty due to limitations in the RSPARROW model. Based on environmental quality standards in China, most water quality classes in the study area were in classes I to III, while some sub-catchments exhibited poor water quality (classes IV to $>$ V; Figure S2).

Seven parameters were selected from an initial 17 parameters to achieve robust model performance with 95\% confidence intervals (Table S3). Sewage discharge (including domestic and industrial discharge), fertilizer application, and livestock manure were identified as key nitrogen sources in the study area. Drainage density and 
slope were identified as major land delivery factors, while stream decay variables were characterized as key water delivery factors. All variance inflation factors were low $(<10)$, indicating that the selected parameters were statistically independent from one another.

\subsection{Beneficiaries}

Hotspots of water withdrawn by industry were mostly distributed in the central urban areas of Longyan City, Yanshi Basin (Figure S3). Water consumed by the public and domestic sectors was related to population density. The Yanshi Basin, Huashan Basin, and the outlet of the Punan Basin were hotspot areas of water withdrawn for human drinking and government use, showing similar trends as industrial water consumption.

\subsection{Ecosystem services cycle}

\subsubsection{Ecosystem services flow}

Water-related ecosystem services supply, beneficiaries, and net change in 11 basins are shown in Figure 3. We found high spatial heterogeneity in water ES supply (quantity and quality) among basins. Basins that provided larger amounts of water showed higher water quality (i.e., lower environmental standards classes), for example as observed in the Zhangping downstream Basin. Some basins contributed less water, and those were typically characterized by a single classification indicating poor water quality (e.g., class $>\mathrm{V}$ for the Chuangchang Basin). The large difference (approaching 1,200 GL) between the largest and smallest basin indicated high heterogeneity in water quantity. Compared to water supply, water consumed by various beneficiaries was more homogeneous, and industry and agriculture consumed the largest amounts of water (Figure $3 b$ ). High water supply and small consumption by beneficiaries contributed to large net surpluses in all but one basin (Figure 3c). ES net surplus was mostly driven by high ES supply, except for the Yanshi and Punan Basins, which experienced smaller surpluses. Zhangzhou Basin showed an ES deficiency, as it consumed more water than was supplied (Figure 3b). 

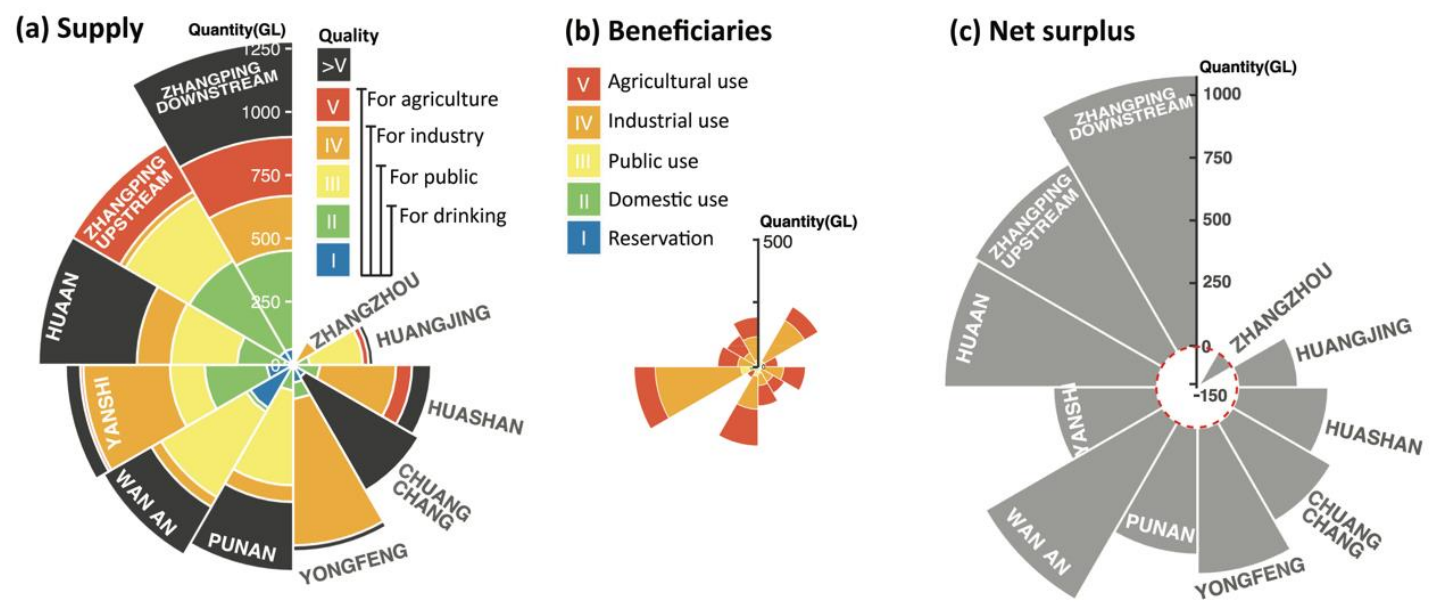

Figure 3. Water ecosystem services supply (a), beneficiaries (b), and net change (c) in 11 basins of the Jiulong River watershed. In panels a) and b), colors show water quality and/or use as indicated by classes I to $>\mathrm{V}$ of the China environmental quality standards. Wherein panel a) presents the potential beneficiaries of different classes (i.e. classes I and II can be used for drinking), while panel b) indicates the actual beneficiaries in different sectors (i.e. class II refers to domestic use). In panel c), the red dashed circle indicates the difference between negative and positive net water surplus.

Overall, water quality improved from upstream areas to downstream areas, with high water quantity in the study area. In the North River, water-related ES flow accumulated from the mid-stream area to the downstream area, accompanied by water quality improvement (Figure 4). Compared to the North River, the West River provided less water, which was of poorer quality in both upstream and downstream regions (Figure 4). 


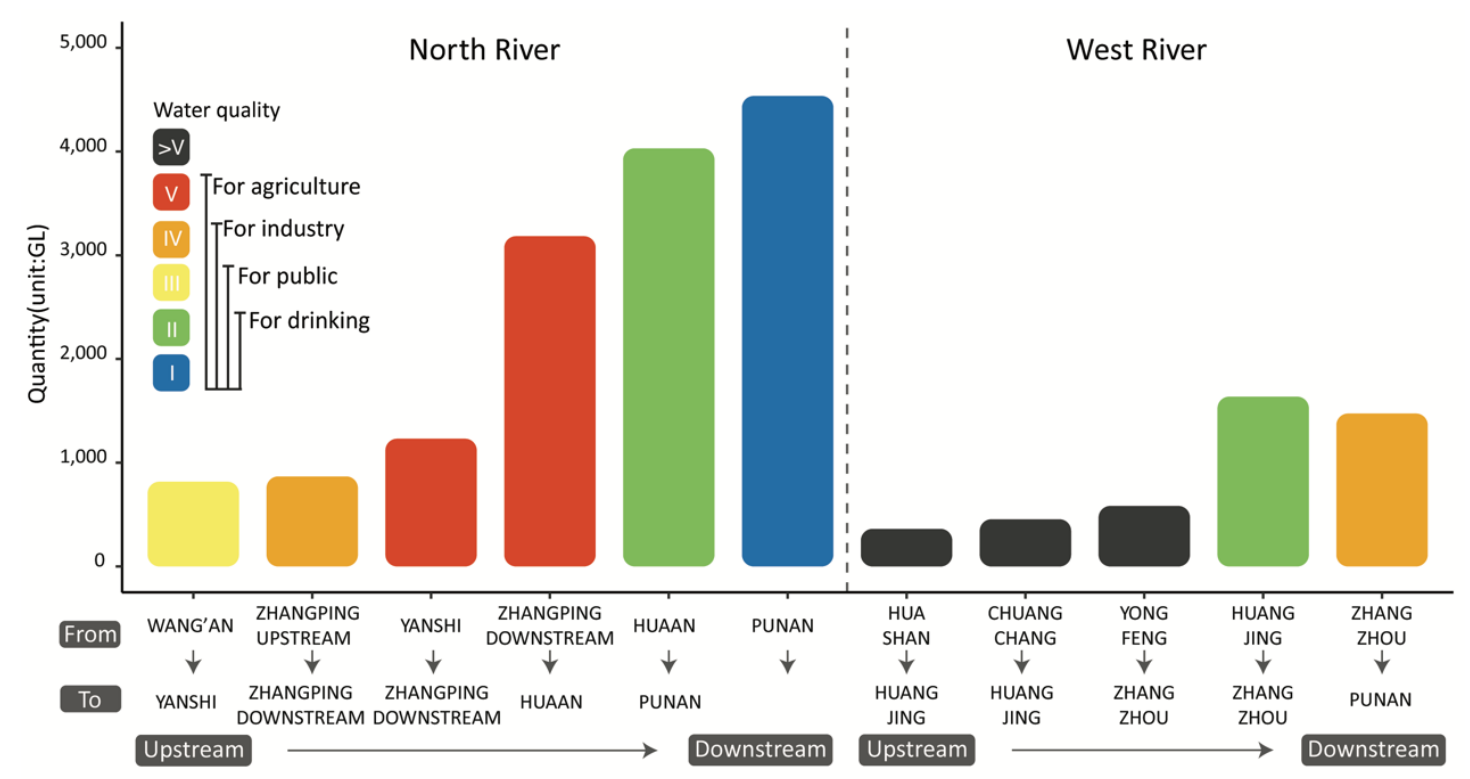

Figure 4. Ecosystem services flow in the North and West Rivers from upstream to downstream areas. Colors indicate water quality classes from I to $>\mathrm{V}$ of the China environmental quality standards.

\subsubsection{Ecosystem disservices}

The interactions of built capital and natural capital contributed to a decrease in EDs (i.e., nitrogen load; Table 1). Nitrogen transport in natural capital diminished remarkably compared to its delivery from built capital in the whole watershed. In comparison to the North River, the West River showed small reductions in nitrogen from built capital but higher reductions from natural capital. Proportions of nitrogen removal from built and natural capitals were higher in downstream areas. 
Table 1. The amount of nitrogen generated from beneficiaries and the proportion of nitrogen removal from built capital and natural capital.

\begin{tabular}{llll}
\hline Basin & $\begin{array}{l}\text { Nitrogen production } \\
\text { (ton year }{ }^{-1} \text { ) }\end{array}$ & $\begin{array}{l}\text { Proportion removed } \\
\text { by built capital }\end{array}$ & $\begin{array}{l}\text { Proportion removed } \\
\text { by natural capital }\end{array}$ \\
\hline North River & $\mathbf{8 2 , 7 7 1}$ & $\mathbf{1 6 . 5 \%}$ & $\mathbf{6 1 . 9 \%}$ \\
\hline WAN'AN & 8710 & $22.3 \%$ & $39.8 \%$ \\
ZHANGPING- & 12,352 & $9.3 \%$ & $47.2 \%$ \\
UPSTREAM & & $30.9 \%$ & $64.3 \%$ \\
YANSHI & 12,840 & $8.6 \%$ & $53.4 \%$ \\
ZHANGPING- & 8550 & $8.6 \%$ & $72.0 \%$ \\
DOWNSTREAM & & $18.7 \%$ & $72.7 \%$ \\
HUA'AN & 16,905 & $\mathbf{5 . 7 \%}$ & $\mathbf{8 6 . 3 \%}$ \\
PUNAN & 23,414 & $2.2 \%$ & $87.6 \%$ \\
\hline West River & $\mathbf{9 7 , 3 6 1}$ & $2.9 \%$ & $94.7 \%$ \\
\hline HUASHAN & 21,519 & $2.3 \%$ & $62.3 \%$ \\
HUANGJING & 16,934 & $2.8 \%$ & $90.1 \%$ \\
CHUANG- & 15,265 & $22.3 \%$ & $93.3 \%$ \\
CHANG & 28,050 & & \\
YONGFENG & 15,361 & & \\
ZHANGZHOU & & & \\
\hline
\end{tabular}

\subsubsection{Ecosystem service cycle}

The interactions of natural capital, built capital, and beneficiaries contributed to spatial heterogeneity in ES flow and EDs in the study area (Figure 5). With a large amount of water, the North River served as a water ES provider for the whole watershed, with good water quality. This was attributed to the installation of drinking water treatment plants, wastewater treatment plants, and their interactions with natural capital, especially in the Hua'an and Punan Basins. Some sub-catchments suffered from waterrelated ES flow deficiencies, such as ES flows from sub-catchments 42 to 41 and 41 to 37 (Figure 5), which were determined by dynamic interactions between natural capital and beneficiaries. These interactions also resulted in the spatial heterogeneity of EDs. Agricultural beneficiaries widely distributed in the West River (e.g., orchards and livestock breeding) generated more EDs, leading to poor water quality and lower water quantity in the West River. Similar trends occurred in the Yanshi Basin of the North River, as most livestock were bred in Longyan City. 


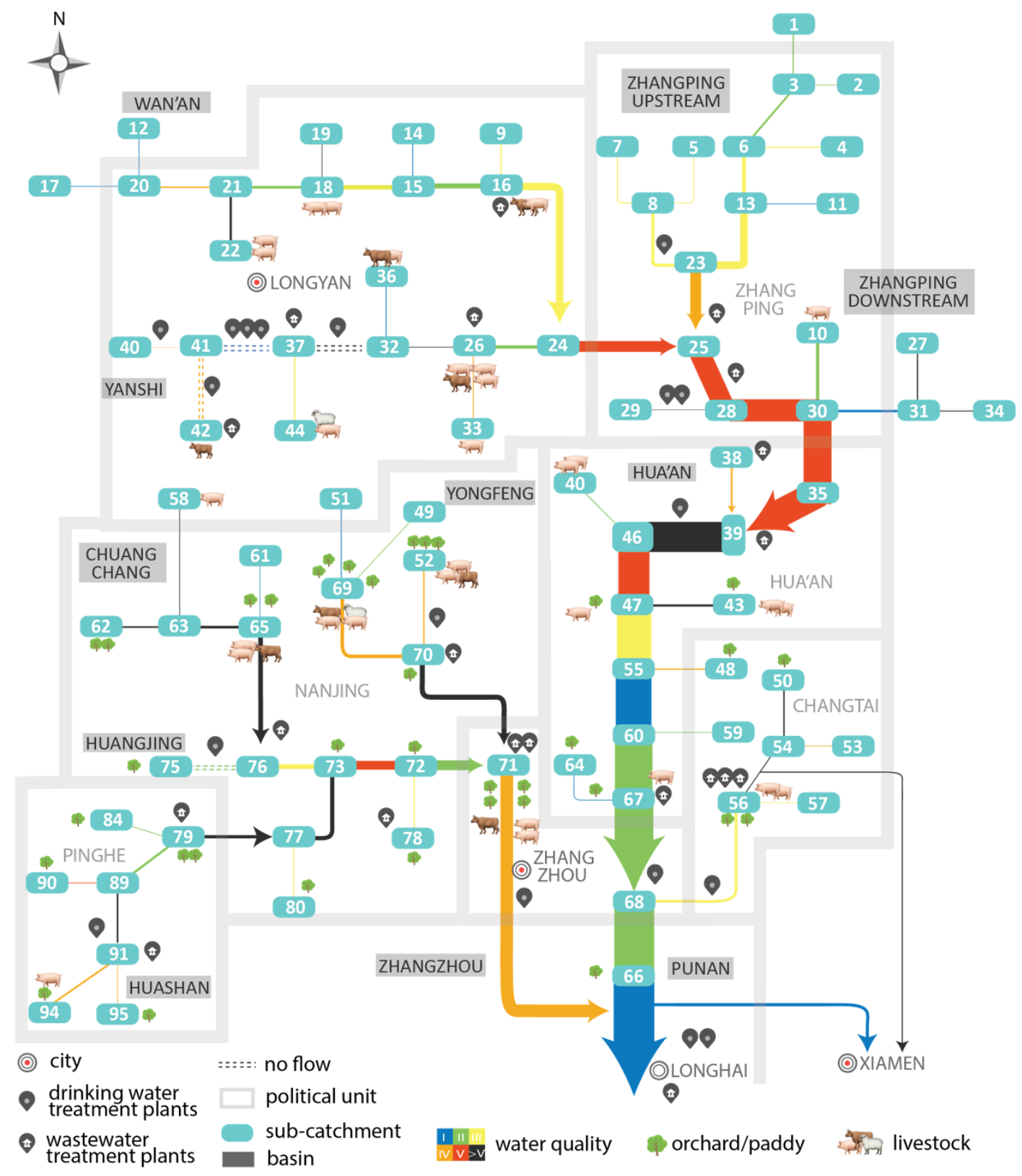

Figure 5. Water ecosystem services cycle in the Jiulong River watershed. The width of the flow bars shows relative water quantity, while the color of the bars indicates water quality (i.e., class as determined by the China environmental quality standards).

\section{Discussion}

In this study, we extended the framing of ES flows as a cycle to illustrate the interactions among natural capital, built capital, and beneficiaries within water-related ES. We applied the framework in the Jiulong River watershed, an important water source for the southern Fujian province, which suffers from serious nitrogen pollution (Du et al., 
2013). We show that the water-related ES cycle is connected by a green phase (ES flow) and a red phase (EDs; Figure 1). In the green phase, the interactions of natural capital and built capital significantly improve water quality in areas with large amounts of water. In the red phase, built capital reduces ED by $\sim 10 \%$ while natural capital reduces this further by over one half. Our new framework can be used to inform the sustainable management of natural capital via eco-compensation schemes, nitrogen management strategies, and built capital interventions.

Water quantity and quality both strongly affected water-related ES supply, with water quantity determining the availability of sufficient ES supply (Grizzetti et al., 2016). Water yield in the study area was influenced by the spatial heterogeneity of climate conditions (including precipitation, evaporation, and temperature), basin topology (including river density and catchment size), and land-use change (Kindu et al., 2016; Lin et al., 2020). This generated large differences in water quantity among basins. With limited water quantity, ES deficiency occurred in the Zhangzhou Basin, making it a recipient of ES from other basins.

The reliability of water ES supply depended on its quality (Ma et al., 2020a). Water quality was affected by the quantity of pollutant sources, eco-hydrological processes, and pollutant control policies (Alexander and Gorman Sanisaca, 2019; Ma et al., 2020b). Regions with lower ES supply (e.g., the Huashan, Chuangchang, and Yongfeng Basins) exhibited poor water quality, which exacerbated water ES scarcity (Mortazavi-Naeini et al., 2019). Changing water quantity and quality also affect many aspects of benefits and costs incurred by beneficiaries (Keeler et al., 2012). Compared to ES beneficiaries in the domestic and public sectors, ES beneficiaries in the industrial and agricultural sectors consumed large amounts of ES, which may indicate that beneficiaries from agriculture and industry seize water ES surplus to satisfy their needs (Wang et al., 2015). Trade-offs might therefore occur within one ES among different stakeholders. In the Punan Basin, industrial activities consumed $\sim 130$ GL, but the sector only supplied $\sim 66$ GL. The remaining $\sim 64$ GL were compensated for by ES surplus from other beneficiaries, such as the domestic and public sectors. For some basins with poor water quality, such as the Zhangzhou Basin, improving water quality to drinking standards 
via chemical treatments might be necessary (Ma et al., 2020b). Beneficiaries from the Zhangzhou Basin need to invest in water quality or pay extra for those services, or else water quality will exacerbate regional water resource inequality (Ma et al., 2020a).

In summary, the green phase of the ES cycle included water ES flows from upstream regions to downstream regions, with improving water quality due to increasing water quantity in downstream regions and dilution (Rice and Westerhoff, 2017). The interaction of natural capital and built capital also affected water-related ES supply. As a mediating factor, drinking water treatment plants contributed to improvements in water quality (Aristi et al., 2015). Built capital (e.g., drinking water treatment plants and piped water connections) served as a connector between natural capital and beneficiaries (Meehan et al., 2020). Drinking water treatment plants managed by the local government can mediate water-related ES demand by setting water prices, with a direct influence on people's willingness to pay (Mu et al., 2019). For example, the urban water pricing reform that adopted increasing block rate tariffs in 2002 in China has reduced annual residential water demand by 3-5\% during 20022009, which help address growing water scarcity (Zhang et al., 2017).

The red phase included the flows of EDs transported from beneficiaries to natural capital, thereby degrading the ecosystem. In this study, EDs were derived from effluents (Lyytimäki et al., 2009), with the quantity of generated EDs determined by pollutant sources such as point sources (i.e., sewage discharge) and non-point sources (i.e., livestock manure, wet deposition, and fertilizer application; Zhou et al., 2018). Intensive agricultural activities such as livestock breeding always led to poor water quality in host basins, for example as in the Chuangchang Basin (Figure 5). However, the same amount of nitrogen applied in two basins could result in different pollution levels, as pollution levels depended on the interconnectivities of beneficiaries, built capital, and natural capital. For most point sources (and partly for non-point sources), treatment by wastewater plants reduced water quality issues in downstream areas, which typically hosted dense populations and urbanized areas (i.e., the Yanshi and Zhangzhou Basins; Acuña et al., 2019). EDs that directly returned to the ecosystem (i.e., most non-point sources), along with drainage from wastewater treatment plants, were 
purely cut down by the ecosystems (Chaplin-Kramer et al., 2019; Díaz et al., 2018; Ervinia et al., 2019). Different capacities for nitrogen depletion might be attributed to the heterogeneity of hydrological connectivity, microbial traits in soil, and biodiversity attributes in different basins (Harrison et al., 2014; Hallouin et al., 2018; Pommier et al., 2018). It is important to note that although nitrogen is lost when transported in the socio-ecological system, the effluents of wastewater treatment plants and most nonpoint sources in watercourses alter many features of freshwater ecosystems and unavoidably degrade water quality (Aristi et al., 2015). Some nature-based solutions, such as green infrastructure (e.g., ecological ditches, buffer strips, and vegetated ponds) can influence pollutant retention in agricultural fields (Berg et al., 2016; Wu et al., 2017).

Our result also indicated that basins with lower ecosystem function and built capital tended to provide more EDs than ES. For example, the downstream areas of the North River, such as the Punan Basin, with a high built capital and natural environment capacity, provided large amounts of cleaner drinking water, while basins with less built capital supplied more EDs (e.g., the Chuangchang Basin). This finding extends existing work that suggests a positive correlation between ecological function and the production of ES and EDs to include both natural environment and built capital (Campagne et al., 2018).

Our study was affected by a number of limitations. In both Punan and Zhengdian stations, HSPF model validation performed poorly due to data accessibility and availability issues (Figure S1). Some observations were not recorded from September 2016 to December 2016 and were imputed using predictive mean-matching methods. This led to inefficient model performance during validation. A limited number of stations with load observations $(\max =18)$ limited the statistical power of the RSPARROW model to detect signals in the data and limited the number of significant explanatory variables that could be included in the model. This created large uncertainties in water quality in the study area. Accurate predictions can be difficult to make for headwater reaches or reaches with small drainage areas, since prediction accuracy typically increases with drainage size (Robertson and Saad, 2011). In addition, we converted the concentration of TN into $\mathrm{NH}_{4}{ }^{+}$using a 30\% fixed coefficient based 
on historical records. There was a standard deviation for the fixed coefficient of $\pm 10 \%$ between the North River and the West River, and a $\pm 3 \%$ standard deviation among seasons, and $9.85 \%$ among the 18 sampling sites. Finally, we only considered waterrelated ES in this study, hence, our framework remains to be extended to further types of ES (i.e. food supply, recreational benefits).

An ES cycle perspective could provide guidelines for eco-compensation. In China, eco-compensation combines ecological compensation and payments for ES, a combination of punitive mechanisms following the 'polluter-pays' principle and incentive-based mechanisms following the 'beneficiary-pays and provider-gets' principle (Shang et al., 2018). The ES cycle characterized ES flows from providers to beneficiaries, providing information for incentive-based mechanisms for ES payments. The ES cycle also illustrated how pollutants led to EDs, potentially informing 'polluterpays' mechanisms. Interactions of different capitals and their impacts on water-related ES can provide a more detailed information for eco-compensation. For example, beneficiaries from areas with lower pollutant retention from ecosystems and built capital may need to pay more for ecological restoration (La Notte et al., 2015).

Nitrogen management strategies, such as improving nitrogen-use efficiency, source reduction, pollutant retention, and restoration or nitrogen resources reallocation, are all practical ways to reduce nitrogen carried into the ecosystem to maintain ecosystem function (Mueller et al., 2017; Wu et al., 2017; Gerber et al., 2016). However, links between such proposed strategies and different capitals are poorly defined. The ES cycle perspective can provide this missing link between pollutant management and different capitals. For example, the contributions of natural capital and built capital to EDs, such as nitrogen removal, nitrogen retention, and waste decomposition, can provide guidelines for pollutant control (Wu et al., 2017). For example, policymakers should balance water-related ES and EDs to decrease the cost of drinking water treatment and wastewater treatment by assessing gross ecosystem products (Ango et al., 2014; Price et al., 2018; Ouyang et al., 2020).

Our study characterized a water-related ES cycle consisting of natural capital, built capital, beneficiaries, and their complex interactions. Our perspective highlighted that 
EDs can be reduced by investing in both built capital and natural capital. More effective strategies are needed to support the sustainable management of natural capital, which aims to ensure the flow of benefits by maintaining the condition of natural capital stocks (Bateman et al., 2020). Built capital, such as gray and green infrastructure, also plays an important role in providing benefits through well-designed interventions (Chen and Graedel, 2015). Yet, we should also be aware that built capital consumes natural resources and induces impacts on the environment, such as climate change and habitat loss (Weisz et al., 2015).

\section{Acknowledgments}

We thank Dr. Richard B. Alexander for guidance on RSPARROW modeling. We thank Deakin University for supporting this research. We thank the National Natural Science Foundation of China [Grant No. 41971231] and the Provincial Natural Science Foundation of Fujian Province [Grant No. 2019J01039] for providing financial support. This work was also supported by the China Scholarship Council [Grant No. 201906310026] and the Fieldwork Funds for graduate students of Xiamen University [Grant No. 2019GF030].

\section{References}

A Level Geography; Website; https://www.alevelgeography.com/drainage-basin-hydrologicalsystem/. 2018.

Acuña, V.; Casellas, M.; Font, C.; Romero, F.; Sabater, S. Nutrient attenuation dynamics in effluent dominated watercourses. Water Research 2019, 160, 330-338. DOI: 10.1016/j.watres.2019.05.093. Alexander, R. B.; Gorman Sanisaca, L. RSPARROW: An R system for SPARROW modeling; U.S. Geological Survey, 2019.

Ango, T. G.; Börjeson, L.; Senbeta, F.; Hylander, K. Balancing ecosystem services and disservices: smallholder farmers' use and management of Forest and Trees in an Agricultural Landscape in southwestern Ethiopia. Ecology and Society 2014, 19 (1), 30. DOI: 10.5751/ES-06279-190130. 
Aristi, I.; Schiller, D.; Arroita, M.; Barceló, D.; Ponsatí, L.; García-Galán, M. J.; Sabater, S.; Elosegi, A.; Acuña, V. Mixed effects of effluents from a wastewater treatment plant on river ecosystem metabolism: subsidy or stress? Freshwater Biology 2015, 60 (7), 1398-1410. DOI: $10.1111 /$ fwb. 12576 .

Bagstad, K. J.; Johnson, G. W.; Voigt, B.; Villa, F. Spatial dynamics of ecosystem service flows: A comprehensive approach to quantifying actual services. Ecosystem Services 2013, 4, 117-125. DOI: 10.1016/j.ecoser.2012.07.012.

Barnes-Mauthe, M.; Oleson, K. L.L.; Brander, L. M.; Zafindrasilivonona, B.; Oliver, T. A.; van Beukering, P. Social capital as an ecosystem service: Evidence from a locally managed marine area. Ecosystem Services 2015, 16, 283-293. DOI: 10.1016/j.ecoser.2014.10.009.

Bateman, I. J.; Mace, G. M. The natural capital framework for sustainably efficient and equitable decision making. Nature Sustainability 2020, 1-8. DOI: 10.1038/s41893-020-0552-3.

Berg, C. E.; Mineau, M. M.; Rogers, S. H. Examining the ecosystem service of nutrient removal in a coastal watershed. Ecosystem Services 2016, 20, 104-112. DOI: 10.1016/j.ecoser.2016.06.007.

Brauman, K. A. Hydrologic ecosystem services: linking ecohydrologic processes to human wellbeing in water research and watershed management. Wiley Interdisciplinary Reviews: Water 2015, 2 (4), 345-358. DOI: 10.1002/wat2.1081.

Campagne, C. S.; Roche, P. K.; Salles, J.M. Looking into pandora’s box: ecosystem disservices assessment and correlations with ecosystem services. Ecosystem Services 2018, 30, 126-136. DOI: 10.1016/j.ecoser.2018.02.005.

Chaplin-Kramer, R.; Sharp, R. P.; Weil, C.; Bennett, E. M.; Pascual, U.; Arkema, K. K.; Brauman, K. A.; Bryant, B. P.; Guerry, A. D.; Haddad, N. M.; Hamann, M.; Hamel, P.; Johnson, J. A.; Mandle, L.; Pereira, H. M.; Polasky, S.; Ruckelshaus, M.; Shaw, M. R.; Silver, J. M.; Vogl, A. L.; Daily, G.

C. Global modeling of nature's contributions to people. Science 2019, 366 (6462), 255-258. DOI: $10.1126 /$ science.aaw3372.

Chen, W.; Graedel, T. E. In-use product stocks link manufactured capital to natural capital. Proceedings of the National Academy of Sciences of the United States of America 2015, 112 (20), 6265-6270. DOI: 10.1073/pnas.1406866112.

China Meteorological Data Service Center; Website; http://data.cma.cn/.

China Statistical Yearbooks; Website; https://data.cnki.net/NewHome/index.

Clark, C. M.; Bell, M. D.; Boyd, J. W.; Compton, J. E.; Davidson, E. A.; Davis, C.; Fenn, M. E.; Geiser, L.; Jones, L.; Blett, T. F. Nitrogen-induced terrestrial eutrophication: cascading effects and impacts on ecosystem services. Ecosphere 2017, 8 (7), e01877. DOI: 10.1002/ecs2.1877.

Costanza, R.; Groot, R. de; Sutton, P.; van der Ploeg, S.; Anderson, S. J.; Kubiszewski, I.; Farber, S.; Turner, R. K. Changes in the global value of ecosystem services. Global Environmental Change 2014 (26), 152-158. DOI: 10.1016/j.gloenvcha.2014.04.002.

Costanza, R.; Groot, R. de; Braat, L.; Kubiszewski, I.; Fioramonti, L.; Sutton, P.; Farber, S.; Grasso, M. Twenty years of ecosystem services: how far have we come and how far do we still need to go? Ecosystem Services 2017, 28, 1-16. DOI: 10.1016/j.ecoser.2017.09.008.

Díaz, S.; Pascual, U.; Stenseke, M.; Martín-López, B.; Watson, R. T.; Molnár, Z.; Hill, R.; Chan, K. 
M. A.; Baste, I. A.; Brauman, K. A.; Polasky, S.; Church, A.; Lonsdale, M.; Larigauderie, A.; Leadley, P. W.; van Oudenhoven, A. P. E.; van der Plaat, F.; Schröter, M.; Lavorel, S.; AumeeruddyThomas, Y.; Bukvareva, E.; Davies, K.; Demissew, S.; Erpul, G.; Failler, P.; Guerra, C. A.; Hewitt, C. L.; Keune, H.; Lindley, S.; Shirayama, Y. Assessing nature's contributions to people. Science 2018, 359 (6373), 270-272. DOI: 10.1126/science.aap8826.

Döhren, P. von; Haase, D. Ecosystem disservices research: A review of the state of the art with a focus on cities. Ecological Indicators 2015, 52, 490-497. DOI: 10.1016/j.ecolind.2014.12.027.

Du, P.; Li, Z.; Huang, J. A modeling system for drinking water sources and its application to Jiangdong Reservoir in Xiamen city. Frontiers of Environmental Science \& Engineering 2013, 7 (5), 735-745. DOI: 10.1007/s11783-013-0560-X.

Ervinia, A.; Huang, J.; Huang, Y.; Lin, J. Coupled effects of climate variability and land use pattern on surface water quality: An elasticity perspective and watershed health indicators. Science of The Total Environment 2019, 693, 133592. DOI: 10.1016/j.scitotenv.2019.133592.

Fujian Provincial Department of Environment Protection; Website; http:/www.fzcangshan.gov.cn/xjwz/xxgk/hjbh/yyssy/202006/t20200630 3345459.htm. 2020.

Gerber, J. S.; Carlson, K. M.; Makowski, D.; Mueller, N. D.; Garcia de Cortazar-Atauri, I.; Havlík, P.; Herrero, M.; Launay, M.; O'Connell, C. S.; Smith, P.; West, P. C. Spatially explicit estimates of $\mathrm{N} 2 \mathrm{O}$ emissions from croplands suggest climate mitigation opportunities from improved fertilizer management. Global Change Biology 2016, 22 (10), 3383-3394. DOI: 10.1111/gcb.13341.

Gong, P.; Li, X.; Zhang, W. 40-Year (1978-2017) human settlement changes in China reflected by impervious surfaces from satellite remote sensing. Science Bulletin 2019, 64 (11), 756-763. DOI: 10.1016/j.scib.2019.04.024.

Grizzetti, B.; Lanzanova, D.; Liquete, C.; Reynaud, A.; Cardoso, A. C. Assessing water ecosystem services for water resource management. Environmental Science \& Policy 2016, 61, 194-203. DOI: 10.1016/j.envsci.2016.04.008.

Guerry, A. D.; Polasky, S.; Lubchenco, J.; Chaplin-Kramer, R.; Daily, G. C.; Griffin, R.; Ruckelshaus, M.; Bateman, I. J.; Duraiappah, A.; Elmqvist, T.; Feldman, M. W.; Folke, C.; Hoekstra, J.; Kareiva, P. M.; Keeler, B. L.; Li, S.; McKenzie, E.; Ouyang, Z.; Reyers, B.; Ricketts, T. H.; Rockström, J.; Tallis, H.; Vira, B. Natural capital and ecosystem services informing decisions: from promise to practice. Proceedings of the National Academy of Sciences of the United States of America 2015, 112 (24), 7348-7355. DOI: 10.1073/PNAS.1503751112.

Guo, Y.; Chen, Y.; Searchinger, T. D.; Zhou, M.; Da Pan; Yang, J.; Wu, L.; Cui, Z.; Zhang, W.; Zhang, F.; Ma, L.; Sun, Y.; Zondlo, M. A.; Zhang, L.; Mauzerall, D. L. Air quality, nitrogen use efficiency and food security in China are improved by cost-effective agricultural nitrogen management. Nature Food 2020, 1 (10), 648-658. DOI: 10.1038/s43016-020-00162-z.

Haines-Young, R.; Potschin, M. The links between biodiversity, ecosystem services and human well-being. In Ecosystem Ecology; Raffaelli, D. G., Frid, C. L. J., Raffaelli, D. G., Frid, C. L. J., Eds.; Cambridge University Press, 2010, 110-139. DOI: 10.1017/CBO9780511750458.007.

Haines-Young, R.; Potschin, M. CICES Version 4: response to consultation, Centre for Environmental Management, University of Nottingham, 2012. 
Hallouin, T.; Bruen, M.; Christie, M.; Bullock, C.; Kelly-Quinn, M. Challenges in using hydrology and water quality models for assessing freshwater ecosystem services: a review. Geosciences 2018, 8 (2), 45. DOI: 10.3390/geosciences8020045.

Harrison, P. A.; Berry, P. M.; Simpson, G.; Haslett, J. R.; Blicharska, M.; Bucur, M.; Dunford, R.; Egoh, B.; Garcia-Llorente, M.; Geamănă, N.; Geertsema, W.; Lommelen, E.; Meiresonne, L.; Turkelboom, F. Linkages between biodiversity attributes and ecosystem services: A systematic review. Ecosystem Services 2014, 9, 191-203. DOI: 10.1016/j.ecoser.2014.05.006.

Herd-Hoare, S.; Shackleton, C. M. Ecosystem disservices matter when valuing ecosystem benefits from small-scale arable agriculture. Ecosystem Services 2020, 46, 101201. DOI: 10.1016/j.ecoser.2020.101201.

Jones, L.; Norton, L.; Austin, Z.; Browne, A. L.; Donovan, D.; Emmett, B. A.; Grabowski, Z.J.; Howard, D. C.; Jones, J.P.G.; Kenter, J.O.; Manley, W.; Morris, C.; Robinson, D. A.; Short, C.; Siriwardena, G. M.; Stevens, C. J.; Storkey, J.; Waters, R. D.; Willis, G. F. Stocks and flows of natural and human-derived capital in ecosystem services. Land Use Policy 2016, 52, 151-162. DOI: 10.1016/j.landusepol.2015.12.014.

Jones, L.; Provins, A.; Holland, M.; Mills, G.; Hayes, F.; Emmett, B.; Hall, J.; Sheppard, L.; Smith, R.; Sutton, M.; Hicks, K.; Ashmore, M.; Haines-Young, R.; Harper-Simmonds, L. A review and application of the evidence for nitrogen impacts on ecosystem services. Ecosystem Services 2014, 7, 76-88. DOI: 10.1016/j.ecoser.2013.09.001.

Keeler, B. L.; Gourevitch, J. D.; Polasky, S.; Isbell, F.; Tessum, C. W.; Hill, J. D.; Marshall, J. D. The social costs of nitrogen. Science Advances 2016, 2 (10), e1600219. DOI: 10.1126/sciadv.1600219.

Keeler, B. L.; Polasky, S.; Brauman, K. A.; Johnson, K. A.; Finlay, J. C.; O’Neill, A.; Kovacs, K.; Dalzell, B. Linking water quality and well-being for improved assessment and valuation of ecosystem services. Proceedings of the National Academy of Sciences of the United States of America 2012, 109 (45), 18619-18624. DOI: 10.1073/pnas.1215991109.

Kim, D.K.; Kaluskar, S.; Mugalingam, S.; Blukacz-Richards, A.; Long, T.; Morley, A.; Arhonditsis, G. B. A Bayesian approach for estimating phosphorus export and delivery rates with the SPAtially Referenced Regression On Watershed attributes (SPARROW) model. Ecological Informatics 2017, 37, 77-91. DOI: 10.1016/j.ecoinf.2016.12.003.

Kindu, M.; Schneider, T.; Teketay, D.; Knoke, T. Changes of ecosystem service values in response to land use/land cover dynamics in Munessa-Shashemene landscape of the Ethiopian highlands. Science of The Total Environment 2016, 547, 137-147. DOI: 10.1016/j.scitotenv.2015.12.127.

Koellner, T.; Schröter, M.; Schulp, C. J.E.; Verburg, P. H. Global flows of ecosystem services. Ecosystem Services 2018, 31, 229-230. DOI: 10.1016/j.ecoser.2018.04.012.

Krkoška lorencová, E.; Harmáčková, Z. V.; Landová, L.; Pártl, A.; Vačkář, D. Assessing impact of land use and climate change on regulating ecosystem services in the czech republic. Ecosystem Health and Sustainability 2016, 2 (3), e01210. DOI: 10.1002/ehs2.1210.

La Notte, A.; Liquete, C.; Grizzetti, B.; Maes, J.; Egoh, B. N.; Paracchini, M. L. An ecologicaleconomic approach to the valuation of ecosystem services to support biodiversity policy. A case 
study for nitrogen retention by Mediterranean rivers and lakes. Ecological Indicators 2015, 48, 292 302. DOI: 10.1016/j.ecolind.2014.08.006.

Lin, J.; Huang, J.; Prell, C.; Bryan, B. A. Changes in supply and demand mediate the effects of landuse change on freshwater ecosystem services flows. Science of The Total Environment 2020, 143012. DOI: 10.1016/j.scitotenv.2020.143012.

Mandle, L.; Shields-Estrada, A.; Chaplin-Kramer, R.; Mitchell, M. G. E.; Bremer, L. L.; Gourevitch, J. D.; Hawthorne, P.; Johnson, J. A.; Robinson, B. E.; Smith, J. R.; Sonter, L. J.; Verutes, G. M.; Vogl, A. L.; Daily, G. C.; Ricketts, T. H. Increasing decision relevance of ecosystem service science. Nature Sustainability 2020, 1-9. DOI: 10.1038/s41893-020-00625-y.

Lyytimäki, J.; Sipilä, M. Hopping on one leg - The challenge of ecosystem disservices for urban green management. Urban Forestry \& Urban Greening 2009, 8 (4), 309-315. DOI: 10.1016/j.ufug.2009.09.003.

Ma, T.; Sun, S.; Fu, G.; Hall, J. W.; Ni, Y.; He, L.; Yi, J.; Zhao, N.; Du, Y.; Pei, T.; Cheng, W.; Song, C.; Fang, C.; Zhou, C. Pollution exacerbates China's water scarcity and its regional inequality. Nature Communications 2020, 11 (1), 650. DOI: 10.1038/s41467-020-14532-5.

Ma, T.; Zhao, N.; Ni, Y.; Yi, J.; Wilson, J. P.; He, L.; Du, Y.; Pei, T.; Zhou, C.; Song, C.; Cheng, W. China's improving inland surface water quality since 2003. Science Advances 2020, 6 (1), eaau3798. DOI: $10.1126 /$ sciadv.aau3798.

Martin-Ortega, J.; Ferrier, R. C.; Gordon, I. J.; Khan, S. Water ecosystem services: A global perspective / edited by Julia Martin-Ortega, The James Hutton Institute, Robert C. Ferrier, The James Hutton Institute, Iain J. Gordon, The James Institute, Shahbaz Khan, UNESCO; International hydrology series; Cambridge University Press, 2015.

Maseyk, F. J.F.; Mackay, A. D.; Possingham, H. P.; Dominati, E. J.; Buckley, Y. M. Managing natural capital stocks for the provision of ecosystem services. Conservation Letters 2017, 10 (2), 211-220. DOI: $10.1111 /$ conl.12242.

Meehan, K.; Jurjevich, J. R.; Chun, N. M. J. W.; Sherrill, J. Geographies of insecure water access and the housing-water nexus in US cities. Proceedings of the National Academy of Sciences of the United States of America 2020. DOI: 10.1073/pnas.2007361117.

Ministry of Ecology and Environment of the People's Republic of China (MEE); Website; http://www.mee.gov.cn/xxgk2018/xxgk/xxgk01/202004/t20200410 773911.html. 2020.

Mortazavi-Naeini, M.; Bussi, G.; Elliott, J. A.; Hall, J. W.; Whitehead, P. G. Assessment of risks to public water supply from low flows and harmful water quality in a changing climate. Water Resources Research 2019, 55 (12), 10386-10404. DOI: 10.1029/2018WR022865.

Motallebi, M.; Hoag, D. L.; Tasdighi, A.; Arabi, M.; Osmond, D. L.; Boone, R. B. The impact of relative individual ecosystem demand on stacking ecosystem credit markets. Ecosystem Services 2018, 29, 137-144. DOI: 10.1016/j.ecoser.2017.12.010.

Mu, L.; Wang, C.; Xue, B.; Wang, H.; Li, S. Assessing the impact of water price reform on farmers' willingness to pay for agricultural water in northwest China. Journal of Cleaner Production 2019, 234, 1072-1081. DOI: 10.1016/j.jclepro.2019.06.269.

Mueller, N. D.; Lassaletta, L.; Runck, B. C.; Billen, G.; Garnier, J.; Gerber, J. S. Declining spatial 
efficiency of global cropland nitrogen allocation. Global Biogeochemical Cycles 2017, 6 (3), 1. DOI: 10.1002/2016GB005515.

Murphy, J.; Sprague, L. Water-quality trends in US rivers: Exploring effects from streamflow trends and changes in watershed management. Science of The Total Environment 2019, 656, 645-658. DOI: $10.1016 /$ j.scitotenv.2018.11.255.

Ouyang, Z.; Song, C.; Zheng, H.; Polasky, S.; Xiao, Y.; Bateman, I. J.; Liu, J.; Ruckelshaus, M.; Shi, F.; Xiao, Y.; Xu, W.; Zou, Z.; Daily, G. C. Using gross ecosystem product (GEP) to value nature in decision making. Proceedings of the National Academy of Sciences of the United States of America 2020, 117 (25), 14593-14601. DOI: 10.1073/pnas.1911439117.

Palmer, M.; Ruhi, A. Linkages between flow regime, biota, and ecosystem processes: Implications for river restoration. Science 2019, 365 (6459). DOI: 10.1126/science.aaw2087.

Pommier, T.; Cantarel, A. A. M.; Grigulis, K.; Lavorel, S.; Legay, N.; Baxendale, C.; Bardgett, R. D.; Bahn, M.; Poly, F.; Clément, J.-C. The added value of including key microbial traits to determine nitrogen-related ecosystem services in managed grasslands. Journal of Applied Ecology 2018, 55 (1), 49-58. DOI: 10.1111/1365-2664.13010.

Price, J. I.; Heberling, M. T. The effects of source water quality on drinking water treatment costs: a review and synthesis of empirical literature. Ecological Economics 2018, 151, 195-209. DOI: 10.1016/j.ecolecon.2018.04.014.

Rice, J.; Westerhoff, P. High levels of endocrine pollutants in US streams during low flow due to insufficient wastewater dilution. Nature Geoscience 2017, 10 (8), 587-591. DOI: 10.1038/ngeo2984. Robertson, D. M.; Saad, D. A. Nutrient inputs to the Laurentian Great Lakes by source and watershed estimated using SPARROW watershed models. JAWRA Journal of the American Water Resources Association 2011, 47 (5), 1011-1033. DOI: 10.1111/j.1752-1688.2011.00574.x.

Schröter, M.; Stumpf, K. H.; Loos, J.; van Oudenhoven, A. P.E.; Böhnke-Henrichs, A.; Abson, D. J. Refocusing ecosystem services towards sustainability. Ecosystem Services 2017, 25, 35-43. DOI: 10.1016/j.ecoser.2017.03.019.

Shang, W.; Gong, Y.; Wang, Z.; Stewardson, M. J. Eco-compensation in China: theory, practices and suggestions for the future. Journal of Environmental Management 2018, 210, 162-170. DOI: 10.1016/j.jenvman.2017.12.077.

South China Institute of Environmental Sciences (SCIES). Handbook of production and discharge coefficient of domestic pollution sources for The Second China Pollution Census. 2019.

South China Institute of Environmental Sciences (SCIES). Handbook of production and discharge coefficient of livestock pollution sources for The First China Pollution Census. 2008.

Steffen, W.; Richardson, K.; Rockström, J.; Cornell, S. E.; Fetzer, I.; Bennett, E. M.; Biggs, R.; Carpenter, S. R.; Vries, W. de; Wit, C. A. de; Folke, C.; Gerten, D.; Heinke, J.; Mace, G. M.; Persson, L. M.; Ramanathan, V.; Reyers, B.; Sörlin, S. Planetary boundaries: guiding human development on a changing planet. Science 2015, 347 (6223), 1259855. DOI: 10.1126/science.1259855.

United Nations Statistic Division (UNSD). System of Environmental-Economic Accounting for Water. United Nations, New York, 2012.

Wang, X.; Yang, H.; Shi, M.; Zhou, D.; Zhang, Z. Managing stakeholders' conflicts for water 
reallocation from agriculture to industry in the Heihe River Basin in Northwest China. Science of The Total Environment 2015, 505, 823-832. DOI: 10.1016/j.scitotenv.2014.10.063.

Weisz, H.; Suh, S.; Graedel, T. E. Industrial Ecology: The role of manufactured capital in sustainability. Proceedings of the National Academy of Sciences of the United States of America 2015, 112 (20), 6260-6264. DOI: 10.1073/pnas.1506532112.

Wu, Y.; Liu, J.; Shen, R.; Fu, B. Mitigation of nonpoint source pollution in rural areas: From control to synergies of multi ecosystem services. Science of The Total Environment 2017, 607-608, 13761380. DOI: 10.1016/j.scitotenv.2017.07.105.

Zhang, B.; Fang, K. H.; Baerenklau, K. A. Have Chinese water pricing reforms reduced urban residential water demand? Water Resources Research 2017, 53 (6), 5057-5069. DOI: 10.1002/2017WR020463.

Zhou, P.; Huang, J.; Hong, H. Modeling nutrient sources, transport and management strategies in a coastal watershed, Southeast China. Science of The Total Environment 2018, 610-611, 1298-1309. DOI: $10.1016 /$ j.scitotenv.2017.08.113. 